\title{
UJI PEMBERIAN PUPUK ISKANDAR MUDA (PIM) ORGANIK TERHADAP PERTUMBUHAN DAN PRODUKSI TANAMAN SAWI (Brassica juncea. L)
}

\author{
${ }^{* 1}$ Afmerta D, ${ }^{2}$ Chairil Ezward dan ${ }^{3}$ Mashadi \\ *1 Prodi Agroteknologi Fakultas Pertanian Universitas Islam Kuantan Singingi \\ e-mail : afmerta d@yahoo.com \\ ${ }^{2}$ Prodi Agroteknologi Fakultas Pertanian Universitas Islam Kuantan Singingi \\ e-mail : chairilezward2709@gmail.com \\ ${ }^{2}$ Prodi Agroteknologi Fakultas Pertanian Universitas Islam Kuantan Singingi \\ e-mail : mashadilendra@gmail.com
}

\begin{abstract}
ABSTRAK
Penelitian ini telah dilaksanakan di Kelurahan Lubuk Jambi Kecamatan Kuantan Mudik Kabupaten Kuantan Singingi. Waktu penelitian dimulai pada Bulan Juni sampai Agustus 2016. Tujuan penelitian ini untuk mengetahui uji pemberian pupuk iskandar muda (PIM) organik terhadap pertumbuhan dan produksi tanaman sawi (Brassica juncea. L). Metode penelitian yang digunakan adalah Rancangan Acak Kelompok (RAK) Non Faktorial yaitu Pupuk Iskandar Muda (PIM) Organik yang terdiri dari 6 taraf perlakuan dan 3 ulangan dengan jumlah plot sebanyak 18 buah dengan ukuran $80 \mathrm{~cm} \times 80 \mathrm{~cm}$. Perlakuan P0 = tanpa pemberian PIM Organik, P1 = Pemberian PIM Organik 0,5 ton/ha, setara dengan 32 gr/plot, $P 2$ = Pemberian PIM Organik 1 ton/ha, setara dengan $64 \mathrm{gr} / \mathrm{plot}, \mathrm{P3}=$ Pemberian PIM Organik 1,5 ton/ha, setara dengan 96 gr/plot, $P 4=$ Pemberian PIM Organik 2 ton/ha, setara dengan $128 \mathrm{gr} / \mathrm{plot}$ dan P5 = Pemberian PIM Organik 2,5 ton/ha, setara dengan $160 \mathrm{gr} / \mathrm{plot}$. Data-data dianalisis secara statistik, dengan uji lanjut beda nyata jujur (BNJ) pada taraf $5 \%$. Berdasarkan hasil penelitian, maka disimpulkan bahwa pemberian Pupuk Iskandar Muda (PIM) organik memberikan pengaruh yang nyata terhadap jumlah daun dan berat segar tanaman. Perlakuan terbaik terdapat pada perlakuan P5 (Pemberian PIM Organik 2,5 ton/ha, setara dengan $160 \mathrm{gr} / \mathrm{plot}$ ) dengan jumlah daun 15,22 helai dan berat segar tanaman 499,56 gram/tanaman.
\end{abstract}

Kata kunci: Sawi, pupuk iskandar muda organik.

\section{ABSTRACT}

This research has been conducted in the village of Lubuk Jambi, subdistrict of Kuantan Mudik, district of Kuantan Singingi. When the study began in June and August 2016. The purpose of this study to determine the test of Pupuk Iskandar Muda (PIM) Organic's to growth and production of mustard (Brassica juncea, L). The method used was a randomized block design (RAK) Non Factorial is Pupuk Iskandar Muda (PIM) Organic consisting of 6 level treatments and 3 replications with plot number as many as 18 pieces with a size of $80 \mathrm{~cm} \times 80 \mathrm{~cm}$. Treatment $P 0=$ without giving PIM Organic, $P 1=$ Giving Organic PIM 0.5 tonnes / ha, equivalent to $32 \mathrm{~g} /$ plot, $P 2$ = Giving Organic PIM 1 ton / ha, equivalent to $64 \mathrm{~g} / \mathrm{plot}, \mathrm{P3}=$ Giving Organic PIM 1, 5 tonnes $/$ ha, equivalent to $96 \mathrm{~g} / \mathrm{plot}$, P4 = Giving Organic PIM 2 tonnes / ha, equivalent to $128 \mathrm{~g} /$ plot and P5 = Giving Organic PIM 2.5 tonnes / ha, equivalent to $160 \mathrm{~g} /$ plot. The data were statistically analyzed, with a further test significant difference honest (HSD) at 5\% level. Based on the findings, it was concluded that the administration of Pupuk Iskandar Muda (PIM) organic significant effect on the number of leaves and the plant fresh weight. The best treatment there in treatment P5 (PIM Organic Provision 2.5 tonnes / ha, equivalent to $160 \mathrm{~g} / \mathrm{plot}$ ) with a number of strands of leaves 15.22 and 499.56 grams of plant fresh weight / plant.

Keywords: Sawi, pupuk iskandar muda organic's. 


\section{PENDAHULUAN}

Sayuran merupakan salah satu tanaman yang sangat berguna dan dibutuhkan dalam kehidupan manusia sehari-hari baik berupa daun, batang, umbi, bunga maupun buah. Sayuran dapat dikonsumsi dalam keadaan segar, dimana peranannya sangat penting dalam menu gizi, terutama sebagai sumber vitamin dan mineral. Bermacam-macam jenis sayuran telah banyak dikenal orang, salah satu diantaranya sawi.

Sawi merupakan jenis sayur yang digemari oleh masyarakat Indonesia. Konsumennya mulai dari golongan masyarakat kelas bawah hingga golongan masyarakat kelas atas. Kelebihan lainnya sawi mampu tumbuh baik di dataran rendah maupun dataran tinggi. Sawi mempunyai nilai ekonomi tinggi setelah kubis krop, kubis bunga, dan brokoli. Sawi diduga berasal dari Tiongkok (Cina), tanaman ini telah dibudidayakan sejak 2500 tahun lalu, kemudian menyebar luas ke Filipina dan Taiwan (Rukmana, 2002). Ditinjau dari aspek klimatologis Indonesia sangat tepat untuk dikembangkan untuk bisnis sayuran seperti tanaman sawi.

Sawi bila ditinjau dari aspek ekonomis dan bisnisnya layak untuk dikembangkan atau diusahakan untuk memenuhi permintaan konsumen serta adanya peluang pasar. Kelayakan pengembangan budidaya sawi antara lain ditunjukkan oleh adanya keunggulan komparatif kondisi wilayah tropis Indonesia yang sangat cocok untuk komoditas tersebut. Disamping itu, umur panen sawi relatif pendek yakni 40 - 50 hari setelah tanam dan hasilnya memberikan keuntungan yang memadai (Rahman, Hermaya dan Lisa, 2008).

Kabupaten Kuantan Singingi merupakan daerah yang cukup berpotensi didalam pembudidaya tanaman sawi, namun kebanyakan petani kurang memahami cara budidaya tanaman sawi yang baik dan benar. Hal ini dapat dilihat dari produksi sawi di Kabupaten Kuantan Singingi secara detail datanya tidak ada, baik yang ada di Dinas Tanaman Pangan maupun Badan Pusat Statistik.
Permasalahan yang dihadapi dalam berusahatani sawi di Kabupaten Kuantan Singingi, diantaranya adalah tanah yang kurang subur, karena jenis tanah didominasi oleh tanah mineral masam dengan jenis tanah Podsolik Merah Kuning (PMK) atau tanah ultisol (Dinas Tanaman Pangan, 2014). Tanah Ultisol sering diidentikkan dengan tanah yang tidak subur, tetapi sesungguhnya bisa dimanfaatkan untuk lahan pertanian potensial, asalkan dilakukan pengelolaan yang memperhatikan kendala yang ada. Beberapa kendala yang umum pada tanah Ultisol adalah kemasaman tanah yang tinggi, $\mathrm{pH}$ rata-rata $<4,50$, kejenuhan $\mathrm{Al}$ tinggi, miskin hara makro terutama $\mathrm{P}, \mathrm{K}$, $\mathrm{Ca}$ dan $\mathrm{Mg}$, serta kandungan bahan organik yang rendah (Prasetyo dan Suriadikarta, 2006).

Salah satu faktor penting dalam budidaya khususnya tanaman sawi yang menunjang keberhasilan adalah masalah pemupukan. Pemupukan adalah tindakan memberikan tambahan unsur-unsur hara pada tanah, baik langsung maupun tak langsung dapat menyumbangkan bahan makanan pada tanaman. Tanaman tidak cukup hanya mengandalkan unsur hara dari dalam tanah saja. Oleh karena itu, tanaman perlu diberi unsur hara tambahan dari luar, yaitu berupa pupuk (Prihmantoro, 2001).

Pemupukan melalui tanah dapat dilakukan dengan pupuk buatan dan pupuk alami. Berkurangnya subsidi pupuk menyebabkan harga pupuk menjadi tinggi. Hal ini perlu dicari alternatif pupuk. Salah satu pupuk yang dapat digunakan adalah pupuk organik.

Begitu pentingnya peranan pupuk organik dalam mendukung pertumbuhan dan produksi tanaman, maka kehadiran produk pupuk organik yang berkualitas sangat didambakan, namun untuk mendapatkan pupuk organik yang berkualitas perlu dilakukan pengujian langsung pada tanaman. Adapun jenis pupuk organik salah satunya yaitu pupuk Pupuk Iskandar Muda (PIM) Organik. Pupuk Iskandar Muda (PIM) Organik mengandung C Organik 13,06\%, N $<6$ 
$\%$, $\mathrm{P}$ dalam $\mathrm{P}_{2} \mathrm{O}_{5}<6 \%, \mathrm{~K}$ dalam $\mathrm{K}_{2} \mathrm{O}<$ $6 \%$. Keunggulan Pupuk Iskandar Muda (PIM) organik yaitu dapat memperbaiki kualitas dan struktur tanah, meningkatkan daya serap dan simpan air, mempercepat perkembangan akar serta sesuai untuk semua jenis tanah dan tanaman (Muchlis, 2011).

Berdasarkan permasalahan diatas, maka penulis telah melakukan penelitian dengan judul "Uji Pemberian Pupuk Iskandar Muda (PIM) Organik Terhadap Pertumbuhan dan Produksi Tanaman Sawi (Brassica juncea. L).

Penelitian ini bertujuan untuk mengetahui uji pemberian pupuk iskandar muda (PIM) organik terhadap pertumbuhan dan produksi tanaman sawi (Brassica juncea. L).

\section{BAHAN DAN METODE}

\section{Tempat Dan Waktu}

Penelitian ini dilaksanakan di Kelurahan Lubuk Jambi Kecamatan Kuantan Mudik Kabupaten Kuantan Singingi. Waktu penelitian akan dimulai pada Bulan Juni sampai Agustus 2016.

\section{Bahan Dan Alat}

Bahan yang digunakan dalam penelitian ini adalah sawi cap panah merah tosakan, Pupuk Iskandar Muda (PIM) Organik, furadan 3G dan bahanbahan lain yang mendukung penelitian ini, sedangkan alat-alat yang digunakan dalam penelitian ini adalah cangkul, handsprayer, timbangan, papan, paku, meteran, kamera dan alat-alat lain yang mendukung penelitian ini.

\section{Metode Penelitian}

Rancangan yang digunakan dalam penelitian ini adalah Rancangan Acak Kelompok (RAK) Non Faktorial yaitu Pupuk Iskandar Muda ( $P$ ) yang terdiri dari 6 taraf perlakuan. Masing-masing perlakuan di ulang sebanyak 3 kali ulangan, jadi diperoleh 18 plot. Setiap plot terdapat 4 tanaman, 3 tanaman diantaranya dijadikan sebagai tanaman sampel. Jumlah tanaman keseluruhan adalah 72 tanaman.
Adapun perlakuannya yaitu Dosis Pemberian Pupuk Iskandar Muda ( P ) sebagai berikut :

$\mathrm{PO}=$ tanpa pemberian PIM Organik

$\mathrm{P} 1$ = Pemberian PIM Organik 0,5 ton/ha, setara dengan $32 \mathrm{gr} /$ plot.

P2 = Pemberian PIM Organik 1 ton/ha, setara dengan $64 \mathrm{gr} /$ plot.

$\mathrm{P3}=$ Pemberian PIM Organik 1,5 ton/ha, setara dengan $96 \mathrm{gr} /$ plot.

P4 = Pemberian PIM Organik 2 ton/ha, setara dengan $128 \mathrm{gr} /$ plot.

$\mathrm{P} 5$ = Pemberian PIM Organik 2,5 ton/ha, setara dengan $160 \mathrm{gr} /$ plot.

\section{Analisis Statistik}

Untuk mendapatkan hasil beserta kesimpulan dari hasil penelitian, maka dilakukan analisis dengan Rancangan Acak Kelompok (RAK) Non Faktorial dengan model analisis data sebagai berikut :

$Y i j=\mu+P i+K j+\varepsilon i j$

\section{Pelaksanaan Penelitian}

Sebelum dilakukan penelitian, lahan dibersihkan dari segala jenis gulma atau sampah sisa tanaman, sampah dikumpulkan menjadi satu kemudian dibuang keluar lahan penelitian.

Selanjutnya dilakukan pengolahan tanah sebanyak 2 kali. Pengolahan tanah pertama dengan membalikan tanah sedalam $25 \mathrm{~cm}$, tanpa menghancurkan bongkahan atau digemburkan tujuannya untuk menetralisir tanah (membuang racun yang berada dalam tanah). Selanjutnya setelah 7 hari, dilakukan pengolahan tanah yang kedua dengan menghancurkan bongkahan - bongkahan tanah dan digemburkan bertujuan agar aerase atau tata udara didalam tanah lebih baik, serta memperbaiki struktur dan tekstur tanah. yang mana akan menguntungkan bagi aktivitas organisme tanah yang dapat meningkatkan kesuburan tanah.

Pembibitan dilakukan bersamaan dengan pengolahan tanah untuk penanaman. Karena lebih efisien dan benih lebih cepat beradaptasi terhadap lingkungannya. Sedang ukuran bedengan pembibitan yaitu lebar $80-120 \mathrm{~cm}$ dan panjangnya $1-3$ meter. Tinggi bedengan $20-30 \mathrm{~cm}$. Dua minggu sebelum di tabur 
benih, bedengan pembibitan ditaburi dengan pupuk kandang sebanyak 3 - 5 ton/ha lalu di tambah 20 gram urea, 10 gram TSP, dan 7,5 gram $\mathrm{KCl}$. Cara melakukan pembibitan ialah sebagai berikut : benih ditabur, lalu ditutupi tanah setebal $1-2 \mathrm{~cm}$, lalu disiram dengan sprayer, kemudian diamati setelah berdaun 4 - 5 helai (3 minggu) tanaman akan dipindahkan ke plot penelitian (penanaman).

Setelah lahan dibersihkan, kemudian dibuat plot yang arahnya menghadap Utara - Selatan. Plot yang akan digunakan untuk penelitian adalah 18 plot, ukuran plot $80 \times 80 \mathrm{~cm}$ dengan jarak antar plot $50 \mathrm{~cm}$ dan jarak antar blok $100 \mathrm{~cm}$.

Fungsi pengapuran untuk menetralkan $\mathrm{pH}$ tanah. Dosis pengapuran 2 ton kapur pehektar (setara dengan 128 gram/plot). cara menentukan kebutuhan kapur perplot $=\frac{\text { luas plot }}{\text { luas } 1 \mathrm{ha}} \mathrm{x}$ dosis anjuran. Jenis kapur digunakan yaitu dolomit. Pemberian dolomit dua minggu sebelum tanam.

Pemasangan label dilakukan dua hari sebelum pemberian perlakuan. Hal ini dilakukan dengan tujuan untuk mempermudah dalam perlakuan dan pengamatan.

Pemberian PIM Organik dilakukan satu minggu sebelum tanam. Dosis pemberiannya sesuai dengan masingmasing perlakuan. Cara pemberiannya yaitu dengan cara disebar, lalu diaduk secara merata pada tiap plot.

Waktu tanam yaitu pada pagi hari antara pukul 06.00 - 10.00 WIB, karena pengaruh sinar matahari dan temperatur tidak terlalu tinggi. Pemindahan bibit ke lahan dilakukan bila bibit telah berdaun 4 - 5 helai karena telah mempunyai perakaran yang kuat. Cara yang dilakukan yaitu dengan sistem cabut, yaitu bibit dicabut dengan hati-hati agar tidak merusak akar. Lalu ditanam pada plot dengan jarak tanam $40 \mathrm{~cm} \times 40 \mathrm{~cm}$. Bibit yang ditanam hanya satu bibit perlubang tanam.

Pupuk anorganik yang diberikan yaitu pupuk yang mengandung unsur Nitrogen (Urea) sebanyak $150 \mathrm{~kg} / \mathrm{ha}$ atau 2,4 gram/tanaman dan pupuk TSP sebanyak $150 \mathrm{~kg} / \mathrm{ha}$ atau setara dengan 2,4 gram/tanaman dan $\mathrm{KCl}$ sebanyak 100 $\mathrm{kg} / \mathrm{ha}$ sebanyak 1,6 gram pertanaman (Haryanto, 2003). Adapun cara mencari dosis pertanaman, terlebih dahulu menentukan jumlah populasi dengan rumus : $\frac{\text { Luas } 1 \mathrm{Ha}}{\text { Jarak Tanam}}$, selanjutnya dapat dicari dosis pertanaman dengan rumus : $\frac{\text { Dosis Anjuran }}{\text { Jumlah populasi }}$, pemberiannya satu minggu setelah bibit pindah tanam.

\section{Parameter Pengamatan}

Parameter yang diamati adalah Tinggi Tanaman $(\mathrm{cm})$, Jumlah Daun (helai), dan Berat segar tanaman (gr/tanaman).

\section{HASIL DAN PEMBAHASAN Tinggi Tanaman (cm)}

Dari hasil pengamatan terhadap parameter tinggi tanaman sawi setelah dilakukan analisis sidik ragam menunjukkan bahwa pemberian Pupuk Iskandar Muda (PIM) organik tidak berpengaruh nyata terhadap tinggi tanaman. Rata - rata tinggi tanaman dapat dilihat pada Tabel 1.

Tabel 1. Rerata Tinggi Tanaman Sawi Dengan Pemberian Pupuk Iskandar Muda (PIM) Organik Umur 28 HSPT (cm)

\begin{tabular}{ccc}
\hline \multicolumn{1}{c}{ Perlakuan } & Rerata (cm) \\
\hline P0 & Tanpa perlakuan (kontrol) & 34,26 \\
P1 $=$ Pemberian PIM Organik 0,5 ton/ha, setara dengan $32 \mathrm{gr} / \mathrm{plot}$ & 34,51 \\
P2 $=$ Pemberian PIM Organik 1 ton/ha, setara dengan $64 \mathrm{gr} / \mathrm{plot}$ & 34,80 \\
P3 $=$ Pemberian PIM Organik 1,5 ton/ha, setara dengan $96 \mathrm{gr} / \mathrm{plot}$ & 37,10 \\
P4 $=$ Pemberian PIM Organik 2 ton/ha, setara dengan $128 \mathrm{gr} / \mathrm{plot}$ & 39,13 \\
P5 $=$ Pemberian PIM Organik 2,5 ton/ha, setara dengan $160 \mathrm{gr} / \mathrm{plot}$ & 40,17 \\
\hline & $\mathbf{K K = 1 3 , 3 1 \%}$ & \\
\hline
\end{tabular}


Berdasarkan Tabel 1 menunjukkan bahwa pada masing-masing perlakuan tidak berpengaruh nyata, namun hasil yang baik terdapat pada perlakuan P5 yaitu $40,17 \mathrm{~cm}$ sedangkan yang terendah pada perlakuan P0 yaitu $34,26 \mathrm{~cm}$. Belum terlihatnya perbedaan tinggi tanaman dari masing-masing perlakuan, hal ini menunjukkan bahwa pada saat pertumbuhan vegetatif yaitu tinggi tanaman, kebutuhan hara bagi tanaman belum terserap secara sempurna. Hal ini disebabkan pupuk iskandar muda yang bersifat lambat melepaskan unsur hara (melepaskan unsur hara secara bertahap) karena harus dirombak terlebih dahulu oleh mikroba untuk bisa menjadi bentuk senyawa yang dapat diserap oleh tanaman, sehingga perbedaan pemberian berbagai dosis belum terlihat secara signifikan. Hal ini sesuai dengan pernyataan Novizan (2005) bahwa pupuk organik yang belum terurai sempurna ratio $\mathrm{C} / \mathrm{N}$ masih tinggi sehingga diberi waktu untuk proses penguraian agar tersedia bagi tanaman.
Novizan (2005) juga menyatakan bahwa unsur hara yang berasal dari pupuk organik sebagian kecil dapat langsung dimanfaatkan oleh tanaman, namun sebagian lagi terurai dalam jangka waktu yang lama. Unsur hara yang terurai tersebut kemudian dapat dimanfaatkan oleh tanaman. Dengan bantuan jasad renik di dalam tanah bahan organik akan diubah menjadi bentuk sederhana yang dapat diserap tanaman (Musnamar, 2005). Oleh karena itu, pupuk organik harus mengalami dekomposisi secara sempurna terlebih dahulu sebelum tersedia bagi tanaman di dalam tanah.

\section{Jumlah Daun (helai) \\ Dari hasil pengamatan terhadap parameter jumlah daun tanaman sawi setelah dilakukan analisis sidik ragam menunjukkan bahwa pemberian Pupuk Iskandar Muda (PIM) organik berpengaruh nyata terhadap jumlah daun. Rata - rata jumlah daun tanaman dapat dilihat pada Tabel 2}

Tabel 2. Rerata Jumlah Daun Tanaman Sawi Dengan Pemberian Pupuk Iskandar Muda (PIM) Organik (helai)

\begin{tabular}{crr}
\hline & Perlakuan & Rerata (helai) \\
\hline P0 & Tanpa perlakuan (kontrol) & $9,67 \mathrm{~b}$ \\
P1 & Pemberian PIM Organik 0,5 ton/ha, setara dengan 32 gr/plot & $11,33 \mathrm{ab}$ \\
P2 $=$ Pemberian PIM Organik 1 ton/ha, setara dengan 64 gr/plot & $12,44 \mathrm{ab}$ \\
P3 $=$ Pemberian PIM Organik 1,5 ton/ha, setara dengan 96 gr/plot & $12,67 \mathrm{ab}$ \\
P4 = Pemberian PIM Organik 2 ton/ha, setara dengan 128 gr/plot & $13,33 \mathrm{ab}$ \\
P5 $=$ Pemberian PIM Organik 2,5 ton/ha, setara dengan 160 gr/plot & $15,22 \mathrm{a}$ \\
\hline KK = 13,37\% & BNJ P = 4,72
\end{tabular}

Angka-angka pada kolom dan baris yang diikuti huruf kecil yang sama menunjukkan berbeda tidak nyata menurut BNJ pada taraf $5 \%$.

Baiknya perlakuan Perlakuan P5 (Pemberian PIM Organik 2,5 ton/ha, setara dengan $160 \mathrm{gr} /$ plot) tak terlepas dari pengaruh pupuk iskandar muda organik yang menjadikan tekstur tanah lebih gembur, sehingga perkembangan akar dapat dengan mudah menembus tanah dan pertumbuhan tanaman tidak terhambat serta bersifat porous sehingga aerasinya sangat baik yang menyebabkan pori-pori media tidak hanya terisi oleh air tetapi terdapat keseimbangan udara dan air yang mengisi pori-pori media. Dengan terbentuknya akar yang memungkinkan proses penyerapan air dan unsur hara lainnya berjalan sempurna yang akhirnya akan berpengaruh terhadap pertumbuhan tunas. Salisbury dan Ross (1995) mengatakan bahwa perakaran akan mendukung terjadinya proses metabolisme tumbuhan karena penyerapan air dan hara terus dipasok oleh akar yang selanjutnya dimanfaatkan untuk pertumbuhan. 
Menurut Kirchner, Wollum dan King (1993), menyatakan bahwa bahan organik dapat memperbaiki struktur tanah, infiltrasi, kesuburan dan daya pegang air yang menciptakan lingkungan yang baik bagi mikroorganisme tanah dalam menambat atau memfiksasi $\mathrm{N}$ sehingga tanaman tumbuh dengan baik. Selanjutnya Sharma (2002) mengemukakan bahwa aktivitas mikroba dalam tanah dapat meningkatkan ketersediaan dan efisiensi penyerapan unsur hara, serta menghasilkan zat pengatur tumbuh yang dapat meningkatkan berkembangnya sistem perakaran.

Rata-rata jumlah daun tanaman sawi terbanyak diperoleh dari perlakuan P5. Hal ini menunjukkan bahwa pemberian PIM Organik 2,5 ton/ha setara dengan 160 gr/plot mampu menyuplai kebutuhan unsur $\mathrm{N}$ pada tanaman sawi. Disamping itu, pupuk iskandar muda organik mampu membantu memperbaiki porositas, sehingga dapat mengatur keseimbangan turgor tanaman, yang diperlukan untuk proses fotosintesis. Hasil fotosintesis akan banyak dimanfaatkan oleh tanaman untuk pertumbuhannya. Hal ini didukung oleh pendapat Harjadi (1988) yang menyatakan bahwa jumlah serapan unsur hara untuk tanaman sangat ditentukan oleh keseimbangan air dan udara didalam media tanam, maka akar tanaman akan menyerap unsur hara dalam jumlah yang cukup sehingga pertumbuhan tanaman akan meningkat.

Pemberian pupuk iskandar muda organik dengan kandungan $N \quad(6 \%)$ dengan berbagai dosis yang diberikan mampu memenuhi kebutuhan akan unsur hara oleh tanaman sawi untuk membentuk jumlah daun yang lebih banyak. Sutedjo (2008) menyatakan bahwa N merupakan unsur hara utama bagi pertumbuhan tanaman, yang pada umumnya sangat diperlukan untuk pembentukan atau pertumbuhan bagian-bagian vegetatif tanaman, seperti daun, batang dan akar.

Berdasarkan data penelitian ini rerata jumlah daun tanaman sawi (helai) dengan pemberian pupuk iskandar muda organik dapat dikalkulasikan dengan pembanding yaitu perlakuan P0 (kontrol) jumlah daun sebanyak 9,67 helai.
Sedangkan jika diberikan pupuk iskandar muda organik 0,5 ton/ha setara dengan 32 gr/plot (P1) maka jumlah daun mengalami pertambahan sebanyak 1,67 helai $(17,24 \%)$, jika diberikan pupuk iskandar muda organik 1 ton/ha setara dengan 64 gr/plot (P2) maka jumlah daun mengalami pertambahan sebanyak 2,78 helai (28,74\%), jika diberikan pupuk iskandar muda organik 1,5 ton/ha, setara dengan $96 \mathrm{gr} / \mathrm{plot}$ (P3) maka jumlah daun mengalami pertambahan sebanyak 3,00 helai $(31,03 \%)$, jika diberikan pupuk iskandar muda organik 2 ton/ha setara dengan $128 \mathrm{gr} /$ plot (P4) maka jumlah daun mengalami pertambahan sebanyak 3,67 helai $(37,93 \%)$ dan jika diberikan pupuk iskandar muda organik 2,5 ton/ha, setara dengan $160 \mathrm{gr} /$ plot (P5) maka jumlah daun mengalami pertambahan sebanyak 5,56 helai $(57,47 \%)$.

Perlakuan P5 (Pemberian PIM Organik 2,5 ton/ha, setara dengan 160 gr/plot) memberikan pengaruh terbaik terhadap parameter jumlah daun tanaman sawi juga disebabkan karena perlakuan P5 juga memberikan tinggi tanaman yang terbaik (Tabel 5) dan dikarenakan pemberian pupuk iskandar muda organik yang dapat menambah hara pada tanaman. Sesuai dengan pendapat Sutedjo (2008) mengatakan bahwa pupuk dapat menambah tersedianya unsur hara bagi tanaman serta jasad renik. Dimana perlakuan P5 disamping memiliki jumlah daun terbaik juga dilihat dari parameter tinggi tanaman juga menghasilkan nilai tertinggi bila dibandingkan dengan perlakuan lainnya. Sesuai degan pandapat Hidayat (1994) mengatakan bahwa pembentukkan daun berkaitan dengan tinggi tanaman, dimana tinggi tanaman dipengaruhi tinggi batang.

Pada perlakuan PO yaitu tanpa pemberian perlakuan terlihat bahwa jumlah daun sedikit. Hal ini dikarenakan tidak adanya penambahan pupuk organik sehingga struktur tanah tidak bagus, infiltrasinya juga kurang baik, kesuburan dan daya pegang airnya juga terhambat. Sarief (1986) mengemukakan bahwa apabila unsur hara kurang mencukupi pada suatu tanaman, maka pertumbuhan tanaman akan terhambat. 
Pada perlakuan P1, P2, P3 dan P4 pupuk yang diberikan dalam jumlah yang kecil, sehingga pertambahan jumlah daun kurang maksimal. Hal ini disebabkan oleh pemberian pupuk yang belum seimbang (dalam jumlah sedikit), sehingga tanaman kekurangan unsur hara sebagai pendukung pertumbuhannya. Sesuai dengan pendapat Dwijoseputro (1996) suatu tanaman akan tumbuh subur apabila semua unsur yang dibutuhkan berada dalam jumlah yang cukup serta dalam bentuk yang sesuai untuk diabsorbsi tanaman. Selanjutnya Setyamidjaja (1986) menyatakan bahwa bila pupuk diberikan dalam jumlah yang terlalu sedikit tidak akan tampak.

Berdasarkan penelitian yang dilakukan Pristianingsih Sarif, Abd. Hadid dan Imam Wahyudi (2015) tentang Pertumbuhan Dan Hasil Tanaman Sawi (Brassica juncea L.) Akibat Pemberian Berbagai Dosis Pupuk Urea menyatakan bahwa pemberian pupuk urea dosis 200 $\mathrm{kg} / \mathrm{ha}$ berpengaruh sangat nyata terhadap jumlah daun (13,40 helai). Berdasarkan penelitian diatas kemudian dibandingkan dengan penelitian saat ini, menunjukkan bahwa hasil penelitian Pristianingsih Sarif, Abd. Hadid dan Imam Wahyudi (2015) memberikan jumlah daun lebih rendah.

Bila dibandingkan dengan deskripsi tanaman sawi untuk jumlah daunnya yaitu berkisar $15-20$ helai, pada penelitian ini perlakuan P5 menghasilkan jumlah daun yang sama dengan deskripsi tanaman, dimana pada perlakuan P5 menghasilkan jumlah daun sebanyak 15,22 helai.

\section{Berat Segar Tanaman (gram/tanaman)}

Dari hasil pengamatan terhadap parameter berat segar tanaman sawi setelah dilakukan analisis sidik ragam menunjukkan bahwa pemberian pemberian Pupuk Iskandar Muda (PIM) organik berpengaruh nyata terhadap berat segar tanaman. Rata - rata berat segar tanaman dapat dilihat pada Tabel 3.

Tabel 3. Rerata Berat Segar Tanaman Sawi Dengan Pemberian Pupuk Iskandar Muda (PIM) Organik (gram/tanaman)

\begin{tabular}{|c|c|c|}
\hline & Perlakuan & Rerata (gr/tan.) \\
\hline P0 & $=$ Tanpa perlakuan (kontrol) & $277,44 \mathrm{~b}$ \\
\hline P1 & $=$ Pemberian PIM Organik 0,5 ton $/$ ha, & $334,67 a b$ \\
\hline $\mathrm{P} 2$ & $=$ Pemberian PIM Organik & $4 a b$ \\
\hline P3 & $=$ Pemberian PIM Organik 1,5 ton/ha, setara dengan $96 \mathrm{gr} / \mathrm{plot}$ & $67 \mathrm{ab}$ \\
\hline $\mathrm{P} 4$ & $=$ Pemberian PIM Organik 2 ton $/$ ha, setara dengan $128 \mathrm{gr} / \mathrm{plot}$ & $422,89 a b$ \\
\hline P5 & $=$ Pemberian PIM Organik 2,5 ton $/$ ha, setara dengan $160 \mathrm{gr} /$ plot & 499,56 a \\
\hline
\end{tabular}

$$
\mathrm{KK}=17,99 \%
$$

BNJ $P=197,80$

Angka-angka pada kolom dan baris yang diikuti huruf kecil yang sama menunjukkan berbeda tidak nyata menurut BNJ pada taraf $5 \%$.

Terbaiknya perlakuan P5 (Pemberian PIM Organik 2,5 ton/ha, setara dengan $160 \mathrm{gr} / \mathrm{plot})$ dikarenakan pada parameter tinggi tanaman (Tabel 5) dan jumlah daun (Tabel 6) juga menunjukkan hasil yang terbaik. Jadi secara langsung akan mempengaruhi berat basah tanaman. Disamping itu, pupuk iskandar muda organik berperan yang sangat penting dalam memperbaiki kesuburan tanah sehingga dapat meningkatkan produksi tanaman sawi. Beberapa pengaruh bahan organik terhadap sifat fisik tanah diantaranya adalah memperbaiki aerasi dan drainase, menjadikan gembur serta memantapkan agregat tanah. Pengaruhnya terhadap kimia tanah yaitu meningkatkan bahan organik tanah yang mengandung unsur hara makro dan mikro (Sarief, 1986).

Ketersediaan hara melalui pemberian pupuk iskandar muda organik mampu menunjang pertumbuhan vegetatif tanaman secara optimal. Ketersediaan unsur hara merupakan salah satu faktor lingkungan yang sangat menentukan laju 
pertumbuhan tanaman (Gardner et al, 1985). Sehingga dibutuhkan lebih banyak unsur hara esensial yang tersedia yang dapat diperoleh melalui peningkatan dosis pupuk iskandar muda organik.

Pupuk Iskandar Muda (PIM) Organik akan menambah ketersediaan hara di dalam tanah. Selain ketersediaan hara di dalam tanah struktur udara dan tata udara tanah sangat mempengaruhi pertumbuhan dan perkembangan akar tanaman. Perkembangan sistem perakaran tanaman yang baik sangat menentukan pertumbuhan vegetatif tanaman yang pada akhirnya akan menentukan produksi tanaman sawi. Kebutuhan akan bemacam-macam pupuk selama pertumbuhan tidak sama, tergantung dari umur dan jumlah pupuknya Sutedjo et al. (2008).

Adanya respon pertumbuhan dan produksi yang baik pada pemberian pupuk iskandar muda organik disebabkan oleh adanya nutrisi yang berupa hara yang terkandung seperti $\mathrm{N}<6 \%$, $\mathrm{P}$ dalam $\mathrm{P}_{2} \mathrm{O}_{5}$ $<6 \%, \mathrm{~K}$ dalam $\mathrm{K}_{2} \mathrm{O}<6 \%$. Peningkatan hasil dari berat segar tanaman sawi sejalan dengan pemberian pupuk iskandar muda organik. Semakin besar dosis yang diberikan semakin meningkat hasil yang diperoleh. Lingga (2007) menyatakan bahwa kemampuan pupuk organik walaupun kuantitasnya sangat sedikit tetapi mampu memberikan pengaruh besar pada tanah yang bisa bermanfaat untuk meningkatkan produktivitas, mempercepat panen, merangsang pertumbuhan akar, batang, daun dan bunga. Hal ini diduga karena kadar haranya tepat untuk kebutuhan tanaman dan penggunaannya lebih efektif dan efisien.

Watanabe (1984) menjelaskan bahwa unsur hara $\mathrm{N}, \mathrm{P}$ dan $\mathrm{K}$ yang terkandung di dalam pupuk organik dapat tersedia bagi tanaman tetapi harus mengalami proses dekomposisi terlebih dahulu di dalam tanah. Pupuk organik merupakan sumber utama hara makro seperti $\mathrm{N}, \mathrm{P}, \mathrm{K}$ dan $\mathrm{S}$ serta unsur hara mikro esensial untuk pertumbuhan dan perkembangan tanaman (Smith, 1993). Selanjutnya Sarief (1986) menjelaskan bahwa pupuk organik mempunyai kemampuan untuk meningkatkan kesuburan tanah karena dapat menambah zat hara, mempertinggi kadar humus, memperbaiki struktur tanah dan mendorong aktivitas jasad renik. Dijelaskan pula bahwa struktur tanah yang baik dapat menunjang laju pertumbuhan dan juga produksi tanaman.

Rata-rata berat segar tanaman dari 6 perlakuan tersebut yaitu $\mathrm{P} 0, \mathrm{P} 1, \mathrm{P} 2$, P3. P4 dan P5 memberikan hasil rata-rata yang meningkat. Peningkatan hasil bobot segar tanaman dapat mencapai hasil yang maksimal, karena tanaman memperoleh hara yang dibutuhkan sehingga peningkatan jumlah maupun ukuran sel dapat mencapai optimal serta memungkinkan adanya peningkatan kandungan air tanaman yang optimal pula. Menurut Loveless (1987) sebagian besar berat basah tumbuhan disebabkan oleh kandungan air. Lebih lanjut menurut Gardner et. al. (1985) berat basah tanaman umumnya sangat berfluktuasi, tergantung pada keadaan kelembaban tanaman, Sedangkan menurut Jumin (2002) menjelaskan bahwa besarnya kebutuhan air setiap fase pertumbuhan berhubungan langsung dengan proses fisiologi, morfologi serta faktor lingkungan.

Perlakuan PO adalah hasil pengamatan terendah, hal ini disebabkan apabila tanaman belum tersedianya kebutuhan unsur hara di dalam tanah dapat menyebabkan perkembangan tanaman terhambat. Menurut Indranada (1986) untuk mencapai produksi yang tinggi, tanaman memerlukan faktor-faktor tumbuh yang optimum. Salah satu faktor tersebut adalah kondisi tanah dan ketersediaan unsur hara.

Berat segar tanaman yang dicapai sedikit lebih tinggi dari potensi hasilnya yaitu mencapai 400 gram pertanaman. Hal ini antara lain dapat disebabkan oleh cocoknya lingkungan bagi tanaman sawi.. Menurut Nurshanti (2010) tanaman sawi dapat tumbuh baik di dataran tinggi maupun dataran rendah. Sedangkan untuk $\mathrm{pH}$ tanah pada lahan penelitian yaitu rata-rata 5,7 , sehingga cocok untuk pertumbuhan tanaman sawi sehingga pertumbuhan dan produksi tanaman yang dihasilkan baik. Selain itu pemberian pupuk organik dengan dosis 2,5 ton/ha mampu menyediakan jumlah 
unsur hara yang baik bagi pertumbuhan tanaman sawi. Hal ini sejalan dengan pendapat Sudiarto dan Gusmaini (2004) bahwa pemanfaatan bahan organik dalam usahatani umumnya harus diikuti dengan pemupukan yang berimbang.

\section{KESIMPULAN}

Berdasarkan hasil penelitian, dengan analisa rancangan RAK non faktorial dapat disimpulkan bahwa pemberian Pupuk Iskandar Muda (PIM) organik memberikan pengaruh yang nyata terhadap jumlah daun dan berat segar tanaman. Perlakuan terbaik terdapat pada perlakuan P5 (Pemberian PIM Organik 2,5 ton/ha, setara dengan $160 \mathrm{gr} / \mathrm{plot}$ ) dengan jumlah daun 15,22 helai dan berat segar tanaman 499,56 gram/tanaman.

\section{DAFTAR PUSTAKA}

Abd Azis. H dan Arman. 2013. Respons Jarak Tanam Dan Dosis Pupuk Organik Granul Yang Berbeda Terhadap Pertumbuhan Dan Produksi Tanaman Jagung Manis. Jurnal Agrisistem, Juni 2013, Vol. 9 No.1.

Cahyono, B. 2003. Teknik dan Strategi Budi Daya Sawi Hijau (Pai-Tsai). Yayasan Pustaka Nusantara. Yogyakarta.

Departemen Pertanian. 2006. Budidaya Kacang Tanah Tanpa Olah Tanah, availableat://www.deptan.go.id/te knologi/tp/tkcgtanah1.htm Agustus 2009]

Dinas Tanaman Pangan Kuantan Singingi. 2014. Laporan Tahunan Dinas Tanaman Pangan. Komplek Perkantoran Pemda Teluk Kuantan.

Dwidjoseputro, D. 1996. Pengantar Fisiologi Tumbuhan. Gramedia. Jakarta.

Fitriani Hamli , Iskandar M. Lapanjang dan Ramal Yusuf. 2015. Respon Pertumbuhan Tanaman Sawi (Brassica juncea L.) Secara Hidroponik Terhadap Komposisi Media Tanam Dan Konsentrasi Pupuk Organik Cair. e-J.
Agrotekbis 3 (3) : 290-296, Juni 2015.

Gardner. F.P., R.B. Pearce and R.I Mitchell. 1991. Fisiologi Tanaman Budidaya. Universitas Indonesia Press. Jakarta

Hadisuwito, Sukamto. 2007. Membuat Pupuk Kompos Cair. PT. Agro Media Pustaka. Jakarta.

Harjadi, S.S dan S. Yahya. 1988. Fisiologi Stress Tanaman. PAU IPB. Bogor

Haryanto, W., T. Suhartini dan E. Rahayu. 2002. Sawi dan Selada. Penebar Swadaya. Jakarta.

Hasibuan, B. 2010. Pupuk dan Pemupukan. Universitas Sumatera Utara Press. Medan.

Heru, P dan Yovita, H. 2003. Hidroponik Sayuran Semusim Untuk Hobi dan Bisnis. Gramedia. Jakarta.

Hidayat, E.B. 1994. Morfologi Tumbuhan. Departemen Pendidikan dan Kebudayaan Direktorat Jendral Pendidikan Tinggi Proyek Pendidikan Tenaga Kerja

https://bp4kgresik.wordpress.com/2013/12 /02/budidaya-tanamanpetsaisawi-brassica-chinensis-l/

Ismaya. 2014. Pengaruh Pupuk Organik Granul Terhadap pertumbuhan Vegetatif Tanaman Cabai Rawit $\mathrm{Rn}$ (Capsicum Frustescens L.). Jurnal Fakultas Keguruan dan Ilmu Pendidikan. Banda Aceh.

Isroi, M. 2008. Kompos. Balai Penelitian Bioteknologi Perkebunan Indonesia Bogor.

Jumin, H.B. 2002. Dasar-Dasar Agronomi. PT. Raja Grafindo. Jakarta. 216 Hal.

Kirchner, M.J., A.G. Wollum, and L.D. King, 1993. Soil Microbiology and Biochemistry. Soil Sci. Am. J., $57: 1289$ - 1295.

Kuyik, Antonius R., Pemmy Tumewu, D.M.F. Sumampow, dan E.G. Tulungen. 2012. Respons Tanaman Jagung Manis (Zea mays saccharata L.) Terhadap Pemberian Pupuk Organik. Jurnal. Fakultas Pertanian Universitas Sam Ratulangi. Manado. 
Lingga, P.. 2007. Petunjuk Penggunaan Pupuk. Edisis Revisi Penebar Swadaya. Jakarta.

Lingga, P. dan Marsono. 2007. Petunjuk Penggunaan Pupuk. Edisis Revisi Penebar Swadaya. Jakarta.

Loveless, A.R. 1987. Prinsip-prinsip Biologi Tumbuhan untuk Daerah Tropik. Penerbit PT. Gramedia. Jakarta.

Madjid, A. R. 2009. Dasar-Dasar IImu Tanah. Fakultas Pertanian Unsri dan Program Pascasarjana Unsri. http://dasar2ilmutanah.com.

Marschner, H. 1986. Mineral Nutrition of Higher Plants. Academic Press Harcourt Brace Jovanovich Publisher, London. Dalam IImu Kesuburan Tanah.ed. Rosmarkam, A. dan N. W. Yuwono. 2002. Kanisius, Yogyakarta.

Muchlis. 2011. PIM Organik. PT Pupuk Iskandar Muda. Aceh.

Murbandono. 2000. Manfaat Bahan Organik bagi Tanaman. Puslit Biologi, LIPI,. Bogor.

Musnamar, E. I., 2005. Pupuk Organik Padat: Pembuatan dan Aplikasi. Penebar Swadaya. Jakarta.

Novizan. 2005. Petunjuk Pemupukkan yang Efektif. Agromedia Pustaka. Jakarta. HIm 97.

Nurshanti DF. 2010. Pertumbuhan dan produksi tanaman sawi (Brasicca juncea L.) dengan tiga varietas berbeda. Agronobis 2(4): 7-10

Prasetyo, B.H dan D.A. Suriadikarta. 2006. Pengembangan Pertanian Lahan Kering di Indonesia. Jurnal Litbang Pertanian $25: 39-47$.

Prihmantoro, H. 2001. Memupuk Tanaman Sayur. Penebar Swadaya. Jakarta.

Pristianingsih Sarif, Abd. Hadid dan Imam Wahyudi. 2015. Pertumbuhan Dan Hasil Tanaman Sawi (Brassica juncea L.) Akibat Pemberian Berbagai Dosis Pupuk Urea. e-J. Agrotekbis 3 (5) : 585591, Oktober 2015

Rahman, A., Hermaya, dan Lisa. 2008. Pertumbuhan dan Produksi Sawi Dengan Pemberian Bokashi. Jurnal Agrisisten 4(2): 75-80
Rukmana, R. 2002. Bertanam Petsai dan Sawi. Kanisius. Yogyakarta.

Salisbury, F.B., dan C.W. Ross. 1995. Fisiologi tumbuhan. Jilid 1 Terjemahan Diah R. Lukman dan Sumaryo. ITB, Bandung.

Sarief, E. S. 1986. Kesuburan dan Pemupukan Tanah Pertanian. Pustaka Buana. Bandung. 182 $\mathrm{hlm}$.

Sastrahidajat, I, H dan Soemono. 1996. Budidaya Tanaman Association. Western Fertilizer Handbook Second Horticulture Edition. Interstate Publishers. INC, Illinois.

Setyamidjaja, D. 1986. Pupuk dan Pemupukan. CV. Simplex, Jakarta.

Sharma , O.P., 2002. Plant Taxonomy. Tata Mc GRaw Hill Publishing Company Limited, New Delhi

Smith, J. L., Papendick, D. F. Bezdicek, J. M. Lynch. 1993. Soil Organic Matter Dynamics and Crop Residue Management. p: 65-94. in : Metting, F. B. (ed.). Soil Microbial Ecology. Marcel Dekker, Inc. New yorkBarselHongkong.

Sirappa, M. P. dan Wahid. 2012. Kajian Tiga Jenis Pupuk Organik Terhadap Pertumbuhan dan Hasil Padi Rawa di Desa Debowae, Kecamatan Waeapo, Kabupaten Buru. Jurnal Budidaya Pertanian. 8(2): 96-100.

Sudiarto dan Gusmaini. 2004. Pemanfaatan bahan organik in situ untuk efisiensi budidaya jahe yang berkelanjutan. Jurnal Litbang Pertanian 23(2): 37-45.

Suhardi. 1990. Dasar-dasar Bercocok Tanam. Kanisius. Yogyakarta.

Sunarjono, H. 2004. Bertanam Sawi dan Selada. Penebar Swadaya. Jakarta.

Sutedjo, M.M. 2008. Pupuk dan Cara Pemupukan. Rineka Cipta. Jakarta.

Suwandi. 2009. Menakar Kebutuhan Hara Tanaman Dalam Pengembangan Inovasi Budidaya Sayuran berkelanjutan. Jurnal Pengembangan Inovasi Pertanian 2 (2): 131-147 
Watanabe, T. 1984. Anaerob Decomposition of Organic Matter in Flooded Rice Soils. In Organik Matter and Rice. IRRI, Los Banos, Laguna, Philipines. 21 hlm.

Yulianti, D. 2010. Pengaruh Hormon Organik dan Pupuk Organik Cair (POC) Super Nasa
Terhadap Produksi Tanaman Jagung Manis (Zea mays saccharata Sturt). http://penelitian-organikpenelitian. com/2010/03/pengaruh-hormonorganik-danpupuk.html.05/04/2011. 